\title{
Fatal Bipolaris spicifera infection in an immunosuppressed child
}

\author{
Carlos G Teran, ${ }^{1}$ Kevin Downes, ${ }^{1}$ Marsha Medows ${ }^{2}$
}

${ }^{1}$ Department of Infectious Diseases, Cincinnati Children's Hospital Medical Center, Cincinnati, Ohio, USA ${ }^{2}$ Department of Pediatrics, New York University, New York, New York, USA

\section{Correspondence to} Dr Carlos G Teran, carteran79@hotmail.com

\section{DESCRIPTION}

A 20-month-old boy with a history of hypoplastic left heart syndrome and a heart transplant was transferred to our institution due to cardiorespiratory failure. His course had been complicated by chronic rejection requiring significant immunosuppression. Over the few weeks prior to transfer, he started developing dark macular skin lesions on the forehead, toes and fingers. The lesions rapidly progressed to necrotic ulcers within approximately 1 month of their onset (figure 1A,B).
At transfer, he was on broad spectrum antibiotic coverage including vancomycin and piperacillintazobactam, as well as prophylactic voriconazole. Because of the symmetric distribution of lesions, disseminated fungal infection with septic emboli was considered and amphotericin was started; an echocardiogram was negative for vegetations. A skin biopsy was obtained and cultures grew Bipolaris spicifera (figure 2A). The patient's mental status gradually deteriorated and a brain MRI showed evidence of possible infection (figure 2B).
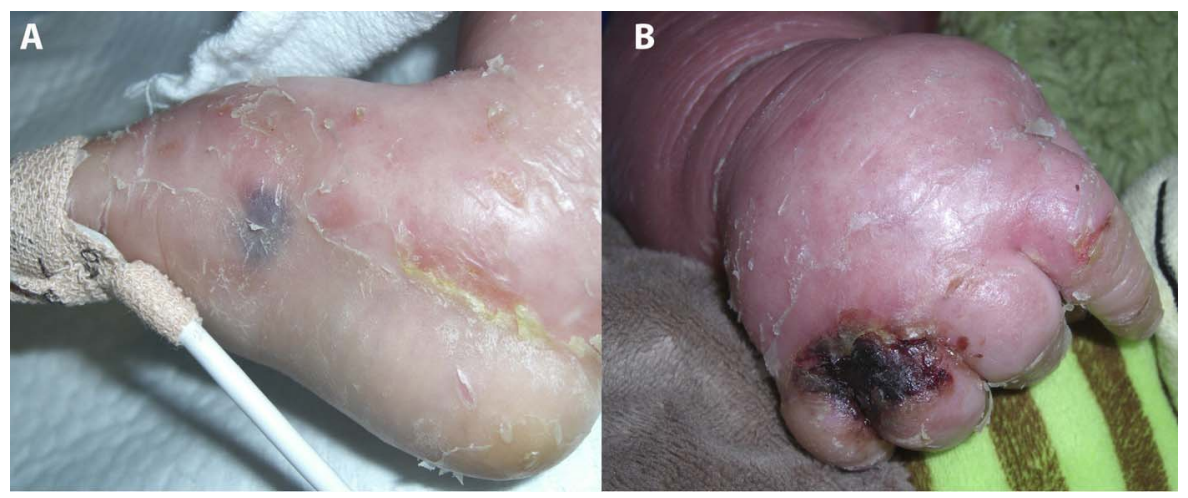

Figure 1 Purple/black lesion on the medial aspect of the right foot $(A)$ and advanced necrotic ulcer on the hand (B); both images were taken on the same day.

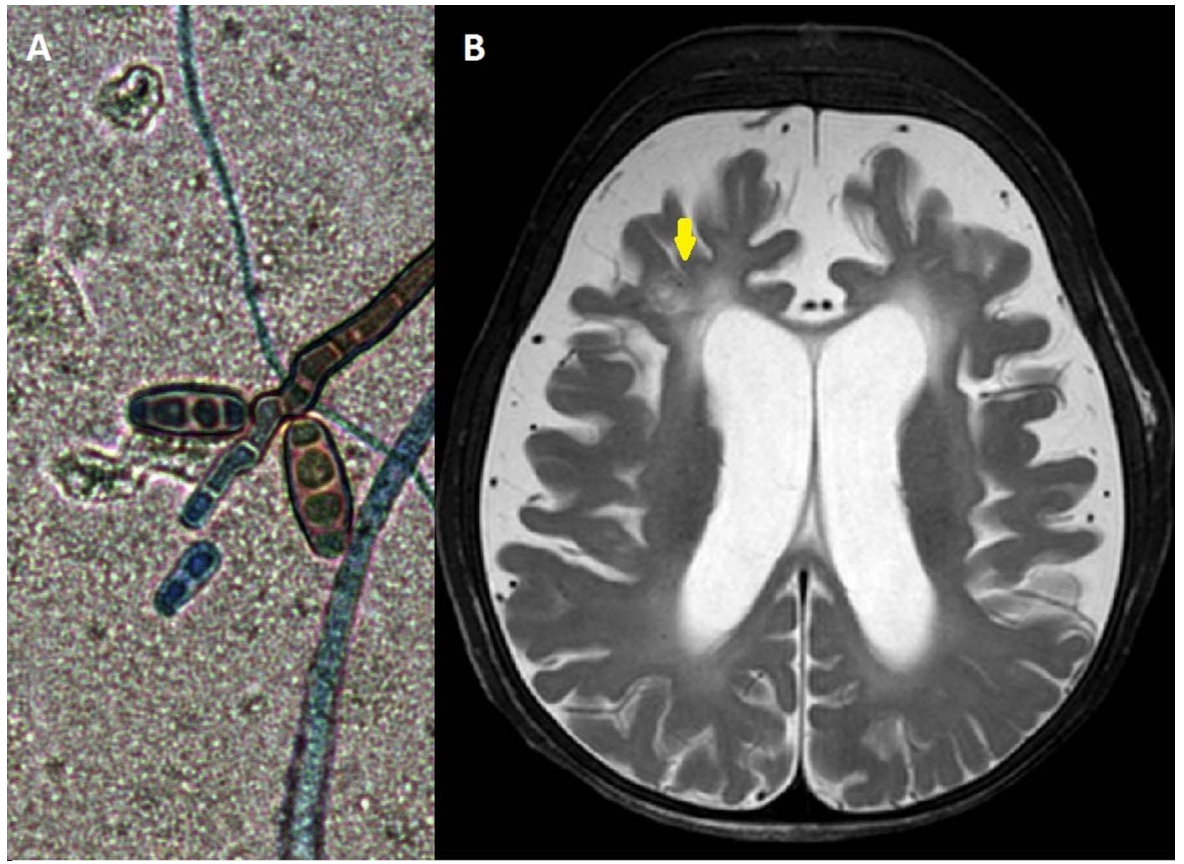

Figure 2 (A) Image showing Bipolaris spicifera hyphae. (B) Brain MRI showing multifocal areas of restricted diffusion (yellow arrow) predominantly along the right periventricular region. 
Despite aggressive medical therapy, the patient had continued progression of skin lesions and died from cardiorespiratory arrest 2 months after the lesions first developed.

$B$ spicifera is a mould rarely associated with disease in humans and clinical presentations vary. ${ }^{1}$ The role of $B$ spicifera in human disease is not well described and is mainly associated with allergic fungal sinusitis. ${ }^{1}{ }^{2}$ Skin manifestations are less often described, generally as part of systemic infection, ${ }^{3}$ as in our case. Our patient developed lesions resembling septic

\section{Learning points}

- Bipolaris spicifera is a mould rarely associated with disease in humans.

- Chronic immunosuppression is a preponderant risk factor for invasive disease.

- Bipolaris species should be considered in the differential diagnosis of necrotic skin ulcers. emboli in the brain and the skin. His history of transplantation and immunosuppression, as well as prolonged antibiotic use, predisposed him to invasive fungal infection. Although rare, it is important to consider this pathogen in the differential diagnosis of necrotic skin lesions, especially when patients are poorly responsive to conventional therapy and in immunosuppressed individuals; antifungals should be initiated early.

Contributors CGT was part of the treatment and follow-up of the patient and wrote most of the manuscript. KD was consultant of the case and edited the manuscript. MM was part of manuscript editing and wrote part of it.

Competing interests None.

Patient consent Obtained.

Provenance and peer review Not commissioned; externally peer reviewed.

\section{REFERENCES}

1 Patherson FT, Sutton DA. Agents of hyalohyphomycosis and phaeohyphomycosis. In: Long SS, Pickering LK, Prober CG, eds: Principles and practice of Pediatric Infectious Diseases. 4th edn. London: Elsevier, 2012:1211-12.

2 Moore ML, Collins GR, Hawk BJ, et al. Disseminated Bipolaris spicifera in a neonate. J Perinatol 2001;21:399-401.

3 Straka BF, Cooper PH, Body BA. Cutaneous Bipolaris spicifera infection. Arch Dermatol 1989;125:1383-6.

Copyright 2014 BMJ Publishing Group. All rights reserved. For permission to reuse any of this content visit http://group.bmj.com/group/rights-licensing/permissions.

BMJ Case Report Fellows may re-use this article for personal use and teaching without any further permission.

Become a Fellow of BMJ Case Reports today and you can:

- Submit as many cases as you like

- Enjoy fast sympathetic peer review and rapid publication of accepted articles

- Access all the published articles

- Re-use any of the published material for personal use and teaching without further permission

For information on Institutional Fellowships contact consortiasales@bmjgroup.com

Visit casereports.bmj.com for more articles like this and to become a Fellow 